\title{
EFEKTIVITAS PIJAT BAYI TERHADAP KENAIKAN BERAT BADAN BAYI DAN KUALITAS TIDUR BAYI USIA 6-12 BULAN
}

\author{
Kumala Sari Rambe ${ }^{1}$, Elfina Ris Imelda ${ }^{2}$ \\ Akademi Kebidanan Baruna Husada Sibuhuan ${ }^{12}$ \\ e-mail: ${ }^{1}$ kumalasarirambe.sst@gmail.com, ${ }^{2}$ elfinaris.imelda@gmail.com
}

\begin{abstract}
Baby massage is useful for increasing the baby's concentration and making the baby sleep soundly. In addition to massage babies, increase milk production, and increase endurance. Based on the results of interviews with 20 mothers who had babies 6-12 months whose baby massage had been carried out, the average mother stated that there was an effect of increased appetite and good sleep quality in infants with data on weight gain in KMS. The research method used pre-experimental design, with the type of pre test and post test one group design and the results of this study were to use the Wilcoxon Signed Ranks Test $p=0.005$, there was the effectiveness of baby massage on baby weight gain and the Wilcoxon Signed Ranks Test $p=0.025$ There is effectiveness in the quality of sleep for infants aged 6-12 months.
\end{abstract}

Keywords: Massage; Weight; Sleep Quality

\begin{abstract}
ABSTRAK
Pijat bayi bermanfaat untuk meningkatkan konsentrasi bayi dan membuat bayi tidur lelap. Selain itu pijat bayi, meningkatkan produksi ASI, Serta meningkatkan daya tahan tubuh. Berdasarkan hasil wawancara dari $20 \mathrm{ibu}$ yang mempunyai bayi 6-12 bulan yang telah dilakukan pemijatan bayinya rata-rata ibu menyatakan ada pengaruh nafsu makan meningkat dan kualitas tidur baik pada bayi dengan data kenaikan berat badan pada KMS. Metode penelitian dengan menggunakan metode pre experimental design, dengan jenis pre test and post test one group design dan hasil penelitian ini adalah dengan menggunakan Uji Wilcoxon Signed Ranks Test $\mathrm{p}=0,005$ terdapat Efektivitas Pijat Bayi terhadap kenaikan Berat badan bayi dan Uji Wilcoxon Signed Ranks Test $\mathrm{p}=0,025$ terdapat efektivitas Kualitas tidur bayi usia 6-12 bulan.
\end{abstract}

Kata kunci: Pijat ; Berat Badan; Kualitas Tidur 


\section{PENDAHULUAN \\ Latar Belakang}

Pijat bayi merupakan terapi sentuh kontak langsung dengan tubuh yang dapat memberikan rasa aman dan nyaman pada bayi. Pijat bayi sangat penting bagi kesehatan bayi, terutama dilakukan oleh orang tua sendiri. Naluri seorang bayi dapat merespon sentuhan dari ibunya sebagai ungkapan rasa cinta, perlindungan, dan perhatian [1].

Tanpa diketahui ketika memandikan bayi, mengeringkan tubuhnya dengan menggosok punggungnya atau bermain-main dengan memijat kakinya, sebenarnya banyak rangsangan pada bayi memang banyak caranya salah satu diantaranya melalui pijatan. Salah satu terapi non farmakologis untuk mengatasi masalah tidur bayi adalah pijat bayi.

Pijat bayi bermanfaat untuk meningkatkan konsetrasi bayi dan membuat bayi tidur lelap, untuk meningkatkan pertumbuhan dan berat badan bayi, meningkatkan daya tahan tubuh, membina ikatan kasih sayang orang tua dan anak serta memperbaiki sirkulasi darah dan pernafasan [1]. Berat badan bayi dipengaruhi faktor keturunan, gizi, lingkunngan, jenis kelamin, dan status sosial. Berat badan merupakan indikator antropometrik untuk menilai tumbuh pada bayi atau anak. Nutsiri yang seimbang serta perawatan kesehatan dasar berupa imunisasi, kontrol ke pusksmas/posyandu secara berkala untuk memantau kesehatan anak [2].

Tidur adalah salah satu bentuk adaftasi terhadap lingkungannya. Sesaat setelah lahir, bayi biasanya tidur selama 16-20 jam sehari. Memasuki usia 2 bulan bayi mulai lebih banyak tidur malam dibanding siang. Sampai usia 3 bulan, bayi baru lahir akan menghabiskan waktu tidurnya sekitar 15-17 jam, dengan pembagian waktu 8 jam untuk tidur siang dan 9 jam untuk tidur malam. Semakin usia bayi bertambah, jam tidurnya juga semakin berkurang. Pada usia 3-6 bulan jumlah tidur siang semakin berkurang, kira-kira 3 kali. Total jumlah waktu tidur bayi usia 0-6 bulan berkisar antara 1315 jam/hari. Pada bayi usia 6 bulan pola tidurnya mulai tampak mirip dengan orang dewasa [3].

Salah satu terapi non farmakologis untuk mengatasi masalah tidur adalah pijat bayi [4], Pijat bayi bermanfaat untuk meningkatkan konsentrasi bayi dan membuat bayi tidur lelap. Selain itu pijat bayi, meningkatkan produksi ASI, Serta meningkatkan daya tahan tubuh [5]..

Berdasarkan penelitian terdahulu telah banyak penelitian pijat bayi dilakukan pada bayi cukup bulan dengan hasil diberikan terapi pijat didapatkan peningkatan berat badan bayi pada kelompok ekpesrimen yang diberikan intervensi terapi pijat lebih tinggi dibandingkan kelompok kontrol [6].
Berdasarkan hasil wawancara dari 20 ibu yang mempunyai bayi 6-12 bulan yang telah dilakukan pemijatan bayinya rata-rata ibu menyatakan ada pengaruh nafsu makan meningkat dan kualitas tidurnya baik pada bayi dengan data kenaikan berat badan pada KMS. Dari latar belakang tersebut maka peneliti tertarik untuk meneliti Efektivitas pijat bayi terhadap kenaikan berat badan dan kualitas tidur pada bayi usia 6-12 bulan di Desa Janji Lobi Lima Kecamatan Lubuk Barumun Kabupaten Padang Lawas.

\section{Tujuan Penelitian}

Tujuan penelitian ini adalah salah satu menganalisis Efektivitas Pijat Bayi bayi terhadap kenaikan berat badan dan kualitas tidur pada bayi usia 6-12 bulan di Desa Janji Lobi Lima.

\section{Hipotesis (Opsional)}

Adakah efektivitas pijat bayi terhadap kenaikan berat badan dan kualitas tidur bayi usia 6-12 bulan.

\section{METODE}

Jenis penelitian yang akan digunakan dalam penelitian ini adalah dengan menggunakan metode pre experimental design, dengan jenis pre test and post test one group design yang dilakukan dengan memberikan perlakukan pada kelompok intervensi sebelum dan sesudah diberikan Pijat Bayi [13].

\section{HASIL}

Tabel 4.1 Karakteristik Responden Bayi berdasarkan Jenis Kelamin

\begin{tabular}{|c|c|c|c|}
\hline No & $\begin{array}{c}\text { Jenis } \\
\text { Kelamin }\end{array}$ & $\begin{array}{c}\text { Jumlah } \\
\text { (orang) }\end{array}$ & $\begin{array}{c}\text { Persen } \\
(\%)\end{array}$ \\
\hline 1 & Perempuan & 14 & 70 \\
\hline 2 & Laki-laki & 6 & 30 \\
\hline \multicolumn{2}{|c|}{ Total } & 20 & 100 \\
\hline
\end{tabular}

Hasil penelitian berdasarkan jenis kelamin pada tabel 4.1 Menunjukkan bahwa responden bayi berdasarkan jenis kelamin dari 20 responden yang paling banyak adalah berjenis kelamin perempuan sebanyak 14 responden bayi (70\%), sedangkan Jenis kelamin Laki-laki berjumlah 6 responden (30\%).

Tabel 4.2 Karakteristik Responden Bayi berdasarkan Umur

\begin{tabular}{|c|l|c|c|}
\hline No & $\begin{array}{c}\text { Jenis } \\
\text { Kelamin }\end{array}$ & $\begin{array}{c}\text { Jumlah } \\
\text { (orang) }\end{array}$ & $\begin{array}{c}\text { Persen } \\
(\%)\end{array}$ \\
\hline 1 & 6 Bulan & 4 & 20 \\
\hline 2 & 7 Bulan & 2 & 10 \\
\hline 3 & 8 Bulan & 4 & 20 \\
\hline 4 & 9 Bulan & 2 & 10 \\
\hline 5 & 10 Bulan & 4 & 20 \\
\hline 6 & 11 Bulan & 3 & 15 \\
\hline 7 & 12 Bulan & 1 & 5 \\
\hline \multicolumn{2}{|c|}{ Total } & 20 & 100 \\
\hline
\end{tabular}


Hasil penelitian berdasarkan umur pada tabel 4.2 Menunjukkan bahwa responden bayi berdasarkan Umur dari 20 responden yang paling banyak adalah pada umur 6 bulan sebanyak 4 responden $(20 \%), 8$ bulan sebanyak 4 responden (20\%) dan 10 bulan sebanyak 4 responden $(20 \%)$, umur bayi 11 bulan sebanyak 3 responden bayi (15\%), dan umur bayi 7 bulan sebanyak 2 responden (10\%), umur bayi 9 bulan sebanyak 2 responden (10\%) sedangkan umur bayi 12 bulan berjumlah 1 responden $(5 \%)$.

Berikut ini pengujian statistik perbandingan kualitas tidur bayi sebelum dan sesudah dilakukan pijat bayi disajikan pada tabel berikut :

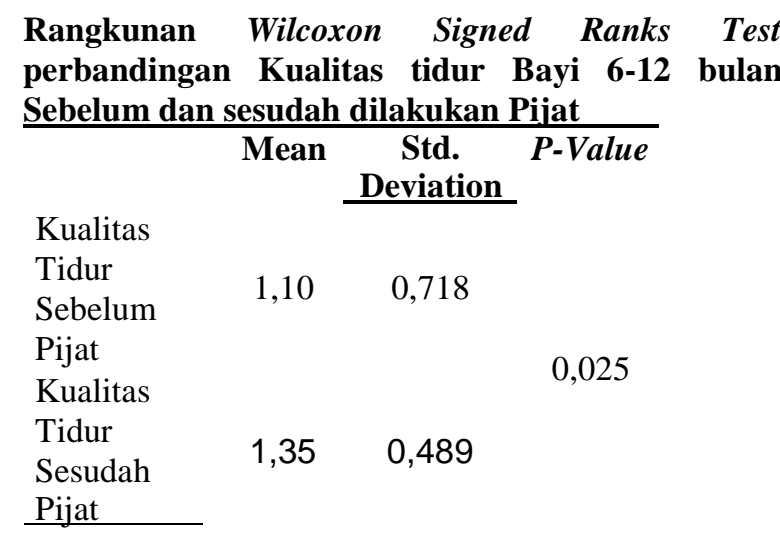

Berdasarkan tabel 4.6 diketahui bahwa terdapat perbedaan berat badan bayi sebelum dipijat dan sesudah dipijat. Hasil uji Wilcoxon Signed Ranks Test diperoleh $\mathrm{p}=0,025$, secara statistik nilai $\mathrm{p}=0,025<$ atau 0,05 maka Ho ditolak dan Ha diterima yang berarti ada pengaruh pijat bayi terhadap perubahan kualitas tidur bayi usia 6-12 bulan di Desa Janji Lobi Lima Kecamatan Lubuk Barumun Kabupaten Padang Lawas tahun 2020.

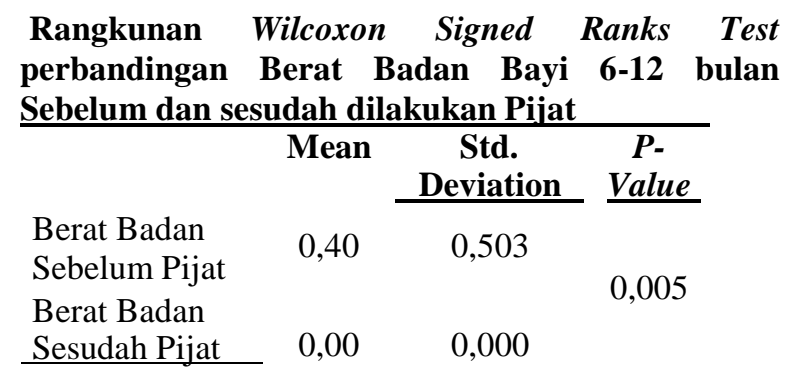

Berdasarkan tabel 4.6 diketahui bahwa terdapat perbedaan berat badan bayi sebelum dipijat dan sesudah dipijat. Hasil uji Wilcoxon Signed Ranks Test diperoleh $\mathrm{p}=0,025$, secara statistik nilai $\mathrm{p}=0,005<\mathrm{atau}$ 0,05 maka Ho ditolak dan Ha diterima yang berarti ada pengaruh pijat bayi terhadap peningkatan berat badan bayi usia 6-12 bulan di Desa Janji Lobi Lima Kecamatan Lubuk Barumun Kabupaten Padang Lawas tahun 2020 .

\section{PEMBAHASAN}

Peningkatan kualitas tidur pada bayi yang diberi pemijatan tersebut disebakan oleh adanya peningkatan kadar sekresi serotonin yang dihasilkan pada saat pemijatan, efek yang terjadi pada tubuh bayi menjadi tenang, nyaman dan mengurangi frekuensi menangis. Rasa nyaman pada bayi setelah dipijat itu seperti apa yang dijelaskan dalam konsep teori kenyamanan yang menjelaskan konsep teori kenyamanan, intervensi kenyamanan, peningkatan kenyamanan [13].

Secara rinci peningkatan berat badan bayi ditunjukkan pada tabel 4.7 berdasarkan hasil uji stastistik dengan menggunakan uji Wilcoxon Signed Ranks Test didapatkan $\mathrm{p}=0,025<0,05$ maka Ho ditolak dan Ha diterima, hal ini menunjukkan ada pengaruh pijat bayi terhadap peningkatan kualitas tidur bayi di Desa Janji Lobi Kecamatan Lubuk Barumun Kabupaten padang lawas.

Dari hasil penelitian dapat disimpulkan bahwa bayi sesudah diberikan pijat bayi akan mengalami peningkatan kualitas tidur dan otomatis kualitas tidur bayi menjadi baik. Dengan kualitas tidur baik, bayi tidurnya akan lebih lama dengan frekuensi bangun yang lebih sedikit, selama tidur bayi tidak rewel, frekuensi menangis bayi akan berkurang dan saat bangun tidur bayi akan tampak ceria. Selain itu pijat bayi juga dapat dilakukan ke semua umur bayi.

Peningkatan berat badan bayi tentunya sangat dipengaruhi oleh pemberian pijat bayi yang diberikan secara kontiniu. Pada dasarnya bayi yang dipijat akan mengalami peningkatan kadar enzim penyerapan terhadap sari makanan pun menjadi lebih baik hasilnya bayi menjadi cepat lapar dan karena itu lebih sering menyusu dan makan. Pemijatan pjuga meningkatkan penyerapan makanan oleh nervus vagus sehingga nafsu makan bayi juga akan meningkatkan yang secara langsung meningkatkan berat badan bayi [14].

Hasil penelitian ini sesuai dengan yang dilakukan di Touch Research Institute Amaerika [15]., yang menunjukkan bahwa anak-anak yang dipijat selama 2x15 menit setiap minggunya dalam jangka waktu 4 minggu, juga memberikan hasil bahwa tidurnya menjadi lebih nyenayk sehingga pada waktu bangun konsentrasinya lebih baik daripada sebelum diberi pemijatana.

\section{KESIMPULAN}

Berdasarkan hasil penelitian dan pembahasan yang ada diatas, maka kesmipulan dalam penelitian ini yaitu sebagai berikut:

1. Berdasarkan hasil uji Wilcoxon Signed Ranks doperoleh nilai $\mathrm{p}=0,025$. Oleh karena hasil perhitungan menunjukkan bahwa $\mathrm{p}<0,05$ maka Ho ditolak, dan Ha diterima. Artinhya terdapat Efektivitas Pijat bayi terhadap Kualitas Tidur bayi menjadi Baik pada usia 6-12 Bulan.

2. Berdasarkan hasil uji Wilcoxon Signed Ranks doperoleh nilai $\mathrm{p}=0,005$. Oleh karena hasil 
perhitungan menunjukkan bahwa $\mathrm{p}<0,05$ maka Ho ditolak, dan Ha diterima. Artinhya terdapat Efektivitas Pijat bayi terhadap Kenaikan Berat Badan bayi menjadi Baik pada usia 6-12 Bulan.

\section{DAFTAR PUSTAKA}

1. Roesli, Utami (2013). Mengenai ASI Eksklusif. PT. Pustaka Pembangunan Swadaya Nusantara, Jakarta.

2. Choirunnisa, (2009). Panduan Terpenting Merawat Bayi dan Balita. Di dalam buku ajar dasar keperawatan anak.. Jakarta: EGC

3. Nursalam, (2013). Konsep penerapan metode penelitian ilmu keperawatan. Jakarta: Salemba Medika

4. Tri SasmiIrva, Oswati Hasanah, Rismadefi (2013), Pengaruh Terapi pijat bayi terhadap peningkatan berat badan bayi. Universitas Riau

5. Cahyaningrum \& Sulistryoni, E (2014). Hubungan pijat bayi terhadap kualitas tidur bayi umur 0-3 bulan di Rb Suko asih sukoharjo tahun 2013. Naskah pubilkasi. Akademi Kebidanan Mamba'ul Ulum Surakarta.

6. Wahida Yuliana, Mohammad Hakimi, Yuli Isnaeni (2013). Efektifitas pijat punggung menggunakan minyak esensial lavender terhadap produksi Asi ibu pasca bersalin. Akbid Hafshawaty Zainul Hasan Genggong Probolinggo.

7. Sulung dkk (2015). Efektifitas Massage Baby terhadap peningkatan berat badan bayi usia 34 bulan di BPS Bunda Kecamatan Mandiangin koto Selayang bukittinggi.

8. Arikunto, S. 2007, Prosedur Penelitian suatu pendekatan praktek edisi revisi VI . Rineka Apta, Jakarta.

9. Praman, A. Mawardi, W (2012). Analisis Perbandingan Tanding Volume Activity dan abnormal return saham sebelum dan sesudah pemecahan saham (studi kasus pada perusahaan yang terdaftar di bursa efek indonesia periode 2007-2011). Diponegoro juornal management.

10. Subakti, Y \& Anggarini, R. 2008. Keajaiban Pijat Bayi dan Balita. Jakarta: PT Wahyu Media.

11. Gola, G. 2009. Ayo Bangun! Dengan Bugar Karena Tidur Yang Benar. Jakarta : Hikmah

12. Prasetyo. 2009. Teknik-teknik Tepat Memijat Bayi Sendiri Panduan Lengkap Dan Uraian Kemanfaatannya. Yogyakarta : Diva Press

13. Hengky W. Pramana, (2012). Aplikasi Inventory Berbasis Access2003.PT. Elex

\section{Media Komputindo, Jakarta}

14. Roesli, U. 2009 Pedoman Pijat Bayi, Edisi Revisi. Jakarta: Pt Trubus Agriwidia

15. Syaukani.A 2015. Petunjuk Praktis Pijat, Senam dan Yoga sehat untuk bayi, Yogyakarta : Araska

16. Roth SL, And Boyle MA. 2010 Personal Nutrition, Seventh Edition, Wadsworth cengage Learning, USA 